\title{
TJPS-47123: Review
}

The Cardiopulmonary Effects of Calcitonin-Gene Related Peptide Family Kalsitonin-Geni İle İlişkili Peptit Ailesinin Kardiyopulmoner Etkileri

\author{
GOKÇEN TELLI ${ }^{1}$, BANU CAHIDE TEL ${ }^{1}$, BÜLENT GÜMÜSEL ${ }^{2}$ \\ ${ }^{1}$ Hacettepe University Faculty of Pharmacy Department of Pharmacology \\ ${ }^{2}$ Lokman Hekim University Faculty of Pharmacy Department of Pharmacology
}

The cardiopulmonary diseases are very common in the population. They are high-cost diseases and there are still no definitive treatments. The roles of members of the calcitonin-gene-related peptide (CGRP) family in the cardiopulmonary diseases have been studied for many years and promising results are obtained. Especially i recent years, two important members of the family, adrenomedullin and adrenomedullin2/intermedin, are considered as new treatment targets in cardiopulmonary diseases. In this review, the roles of CGRP family peptides in cardiopulmonary diseases has been investigated according to the studies that were performed to the present day.

Keywords: CGRP family, cardiopulmonary diseases, adrenomedullin, adrenomedullin2/intermedin, pulmonary hypertension

Kardiyopulmoner hastalıklar toplumda sık görülen, tedavi maliyeti oldukça yüksek ve halen kesin bir tedavisi bulunmayan hastalıklardır. Kalsitonin-geni ile ilişkili peptit ailesinin üyelerinin bir çok kardiyopulmoner hastalıktaki rolleri uzun yıllardır çalışılmakta ve umut vadeden sonuçlar elde edilmektedir. Özellikle son yıllarda CGRP ailesine ait peptitlerden adrenomedullin ve intermedin kardiyopulmoner hastalıklarda yeni tedavi hedefleri olarak değerlendirilmektedir. Bu derleme ile CGRP ailesi peptitlerinin kardiyopulmoner hastalıklardaki roller günümüze kadar yapılan çalışmalar doğrultusunda incelenmiştir.

Anahtar Kelimeler: CGRP ailesi, kardiyopulmoner hastalıklar, adrenomedullin, adrenomedullin2/intermedin, pulmoner hipertansiyon

\section{INTRODUCTION}

The calcitonin-gene related peptide (CGRP) family consists of calcitonin, amylin (AMY), CGRP, adrenomedullin (ADM), calcitonin receptor stimulating peptide 1-3 and the latest member of the family, adrenomedullin2/intermedin (ADM2/IMD) $)^{1,2}$. These peptides are included in the same family because of the similar chemical structures and have important roles in the homeostasis of the body ${ }^{3-6}$. The effects of these peptides on cardiovascular and pulmonary system, especially ADM and ADM2/IMD, sparked an interest as many studies were presented for the new targets of cardiovascular diseases ${ }^{7-9}$. In this review, we aim to summarize the cardiopulmonary effects of CGRP family.

\section{The distribution of the Calcitonin-Gene Related Peptide family peptides}

The peptides of the CGRP family are widely expressed in the body. The first peptide of this family, calcitonin, is synthesized by a calcium-dependent mechanism and released from thyroid C-cells ${ }^{10,11}$. Another peptide, amylin, was isolated from amyloid plaques in $\beta$-cells where found in the pancreatic islets of the Langerhans ${ }^{12}$. The rest of the family; CGRP, ADM, ADM2/IMD; is more effective on the cardiovascular and pulmonary system. The CGRP expressed in the both central and peripheral nerves that associated with blood vessels. Perivascular nerves were suggested as important sources of plasma CGRP. Although CGRP is mainly expressed in nerves, it is also located in endothelial cells, adipocytes, keratinocytes, immune cells ${ }^{13}$.

$\mathrm{ADM}$ was isolated from human pheochromocytoma cells for the first time, however in following years has been shown to be expressed in many tissues in the body ${ }^{14}$. It is found in adrenal medulla, kidney, lungs, ventricles and especially endothelial cells in high amounts ${ }^{15,16}$.

The distribution of ADM2/IMD is largely similar with ADM. The expression of ADM2/IMD was demonstrated in brain, liver, intestine, heart, kidney, plasma, hypothalamus and like ADM widely in endothelial cells ${ }^{17-22}$. In addition to being expressed widely in physiological conditions, their levels change under pathological conditions ${ }^{13,23-26}$.

\section{The Receptors of Calcitonin-Gene Related Peptide Family}

The peptides of CGRP family interact with calcitonin receptors (CTR) or calcitonin receptor-like receptors

(CLR). CTR first identified in pigs in 1991 and two different variants was found in human which was called $\mathrm{hCT}_{\mathrm{a}} \mathrm{R}$ ve $\mathrm{hCT} \mathrm{T}_{\mathrm{b}} \mathrm{R}$. These receptors are located on cell surface. The hCTaR is widely distributed in the body, however the hCTbR was found in placenta, ovary, lung and bone marrow ${ }^{27}$. The CLRs were first demonstrated in rats in 1993 and 2 years later were showed in different tissues of human ${ }^{28,29}$. CLRs were found in the central nervous system, kidney and spleen, endothelial cells, vascular smooth muscle cells and the heart. CTRs and CLRs are $\mathrm{G}$ protein-dependent receptors and contain 7 transmembrane regions ${ }^{30,31}$. The receptors must also interact with the related receptor-activating modified protein (RAMP), depending on the type of peptide. These 
proteins facilitate the transfer of receptors from the plasma membrane and translocations of them into the cells $^{32,33}$. RAMPs are composed of 148 to 189 aminoacids and although they exhibit a homology less than $30 \%$, they are structurally similar to each other. These proteins are named RAMP-1, RAMP-2 and RAMP- $3^{13}$. AMY shows high affinity when CTRs are activated by RAMPs ${ }^{33,34}$. RAMPs that bind to CTR allow the receptor to show affinity to AMY instead of calcitonin. When the CTRs are connected with RAMP1, RAMP2 and RAMP3 is called as AMY1, AMY2 and AMY3; respectively. CGRP and ADM are activated by binding to CLRs. CLRs must interact with RAMP1 in order to function as CGRP receptors. CLRs must be bound to RAMP2 and -3 to act as an ADM receptor (AM1 and AM2, respectively) (Table1.).

Table 1. The receptors and receptor components that interacts with CGRP family

\begin{tabular}{|l|l|l|}
\hline Receptor & Receptor Component & Agonist \\
\hline CGRP & CLR/RAMP1 & CGRP, ADM2/IMD \\
\hline AM1 & CLR/RAMP2 & ADM, ADM2/IMD \\
\hline AM2 & CLR/RAMP3 & ADM, CGRP, ADM2/IMD \\
\hline Calcitonin & CTR & CT, CRSP \\
\hline AMY1 & CTR/RAMP1 & AMY, CGRP \\
\hline AMY3 & CTR/RAMP3 & AMY \\
\hline
\end{tabular}

RAMP1 is commonly found in the uterus, bladder, brain, pancreas and gastrointestinal tract ${ }^{35-37}$. It has been also shown in veins, perivascular nerves, arteries and arterioles of endothelial cells and smooth muscle cells and cardiomyocytes $^{38}$. RAMP2 is found in lungs, spleen, immune system, kidney and widely distributed in the cardiovascular system, especially in vascular endothelium and smooth muscle cells ${ }^{39}$. RAMP3 is found highly in kidneys, lungs and spleen similar with RAMP2 $2^{35,36}$.

Other than RAMPs, CLRs need another adapter protein to show its optimum activity. This protein called receptor component protein (RCP) and provides a more effective binding with stimulator G protein (Gs) thus, increases activity of peptides ${ }^{32,40}$ (Figure 1.).

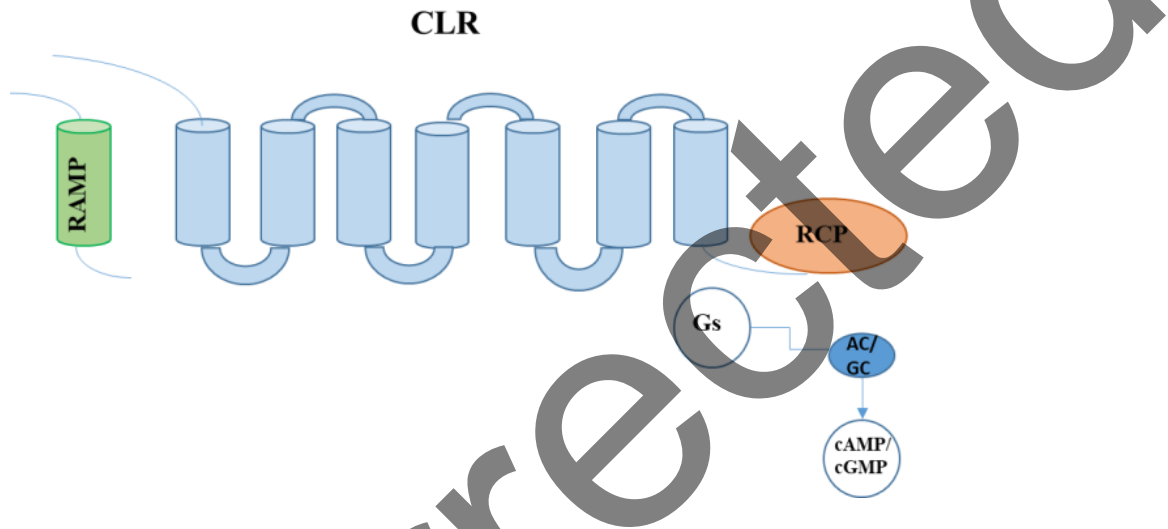

Figure1. CLRs are G protein-đependent receptors and contain 7 transmembrane domain.CLRs requires RAMPs and RCP for activation. The activated CLRs stimulate the G protein complex and provide activity.

Cardiopulmonary effects of the Calcitonin-Gene Related Peptide Family

The peptides of CGRP family show widespread biological activity in the body, and in the cardiopulmonary system especially CGRP, ADM and ADM2/IMD, has remarkable effects.

\section{Amylin(AMY)}

AMY acts on the cardiovascular system via CGRP receptors ${ }^{41}$. However, AMY has to reach high plasma concentration to show activity. The intravenous (i.v.) AMY application provided potent vasodilatation and decreased arterial blood pressure in rats ${ }^{42}$. However, human studies showed no significant effect after AMY application ${ }^{43}$. Studies on rat cardiomyocytes and isolated heart, AMY showed a direct inotropic effect that mediated by CGRP receptors. However, because of the high doses AMY application side-effects on the heart, it was discussed that AMY could not be applied to the clinic ${ }^{44,45}$.

\section{Calcitonin Gene Related Peptide (CGRP)}

CGRP is one of the most potent and effective vasodilator and it has a longer duration of action ${ }^{46,47}$. The relaxing effect of coronary, cerebral, pulmonary and renal arteries were shown in both in vitro and in vivo experiments. CGRP has also regulatory effects on the vascular system, it was shown to reduce the vascular resistance and to increase the blood supply to organs in both normotensive and hypertensive animals ${ }^{48,49}$. In hypertensive rats, the systemically administrated CGRP decreased the blood pressure and had positive inotropic and chronotropic effects. After ischemic injury CGRP released in rats and also CGRP infusion reduced ischemia-reperfusioninduced arrhythmias. In addition, many studies have shown that CGRP also protective against ischemic damage. These effects of CGRP are generally thought to be the result of vasodilatory effect ${ }^{50-52}$. Furthermore CGRP also suppressed the releasing of potent vasoconstrictor agents such as endothelin and angiotensin ${ }^{53}$. 
CGRP provided important relaxation in the pulmonary vascular system and was found high amount in lung tissue $^{54}$. In pulmonary hypertension (PH) the plasma CGRP levels were decreased and CGRP infusion has been shown to be effective in the treatment ${ }^{13,23-25}$. The adenovirus-mediated CGRP transfection before chronic hypoxia exposure in mice lungs provided cyclic adenosine monophosphate (cAMP)-mediated protection against pulmonary vascular resistance and decreased the vascular remodelling ${ }^{53}$. CGRP has been shown to provide protection against hypoxia-induced remodeling in human tissue studies ${ }^{55}$ and it was showed that in rat hypoxic lung the expression levels of the CGRP receptor adapter protein RAMP1 were increased ${ }^{26}$.

CGRP shows all these effects through CGRP receptor and the effects of CGRP on the cardiovascular system are inhibited in the presence of selective CGRP antagonist CGRP 8-37 $^{46,56-58}$. It is suggested that both endotheliumdependent and endothelium-independent mechanisms has roles in CGRP-mediated vasodilatation ${ }^{5,59,60}$. In many tissues, such as cat cerebral artery, rat mesenteric artery and pig coronary artery, the increase in cAMP was measured after CGRP administration and in the endothelium-damaged vessels the vasodilation was also observed. However, even high doses CGRP did not stimulate the cylic guanosine monophosphate (cGMP) levels directly ${ }^{59,60}$. Therefore, it may indicate that CGRP directly activates the cAMP-dependent vasodilation ${ }^{61-63}$. In the studies that were performed in pig coronary artery and guinea pig uretery, CGRP-mediated vasodilation was inhibited with $\mathrm{K}_{\text {ATP }}$ channel inhibitor glibenclamide. Therefore, it was discussed that the increase in cAMP activates protein kinase $\mathrm{A}$ and subsequently $\mathrm{K}_{\mathrm{ATP}}$ channels ${ }^{61,63-67}$. Basal and NO-stimulated CGRP release was increased in the human right atrium in the patients that was performed cardiopulmonary bypass ${ }^{68,69}$. However, there are also contradictory studies indicated the role of endothelium in CGRP-mediated vasodilation. CGRP provided nitric oxide (NO) and cGMP -dependent vasodilation in rat aorta ${ }^{70}$. On the other hand in the perivascular nerves of rat mesentery artery, CGRP was found more sensitive to endothelin-1 mediated constructions and this effect was not associated with NO or cylic nucleotides ${ }^{71}$.

\section{Adrenomedullin (ADM)}

In many years, ADM was drawn attention to the effects on cardiovascular system. A potent, NO-mediated hypotension was observed after the infusion of ADM both in animals and in humans ${ }^{72-74}$. After acute and chronic administration of ADM in rats, total peripheral vascular resistance and blood pressure was decreased significantly. The heart rate and cardiac output were increased simultaneously. Similar effects were also observed in hypertensive rats ${ }^{75,76}$. ADM is an important vasorelaxant agent, especially in the mesentery, renal, pulmonary, cerebral arteries and aorta, but the mechanism of this effect yaries according to species and the vascular bed ${ }^{77-80}$. The vasorelaxing effects act through CGRP and ADM receptors. In the rat mesenteric artery and dog renal arteries, the relaxing effect of ADM was inhibited in the presence of CGRP receptor antagonist, whereas in some studies that were performed in cerebral arteries of cat and rat hind limb, inhibition of CGRP receptors did not alter the relaxation response ${ }^{78,81,82}$. Similarly, the role of endothelium and NO in the relaxation effect of ADM was also varies between different studies. Numerous studies have shown that endotheliummediated vasorelaxation was occurred in different vessels such as rat renal, pulmonary, mesenteric artery and the vasorelaxation was inhibited in the presence of nitric oxide synthase (NOS) inhibitors ${ }^{72,83,84}$. However, in contrary to these studies, no changes were observed in the presence of NOS inhibitor in the studies that were performed in isolated rat lung, cat hind limb arteries, cat penile artery studies ${ }^{85-87}$. Studies in human and dog coronary arteries and rat cerebral arteries have inhibited ADM response with high potassium ${ }^{78,88,89}$. Although there are contradictory results in the literature, it has been shown in many studies that the ADM provides relaxation through the eAMP, $\mathrm{NO}$ or $\mathrm{K}^{+}$channels in vascular systems ${ }^{90}$.

According to its potent and long-lasting vasodilatory activity in the peripheric microcirculation, ADM also could be effective in $\mathrm{PH}^{91}$. In hypoxia-induced $\mathrm{PH}, \mathrm{ADM}$ reduced the pulmonary arterial pressure ${ }^{92}$. Systemic i.v. administration of ADM reduced pulmonary vascular resistance and increased the arterial oxygen levels without no effect in the systemic blood pressure ${ }^{93}$. In the studies that was performed on PH patients; the plasma level of $\mathrm{ADM}$ was increased along with the severity of the disease. In contrast to the increase of the endogenous production of ADM, i.v. ADM administration reduced pulmonary artery pressure and pulmonary vascular resistance in $\mathrm{PH}$ patients ${ }^{94,95}$. In another study performed with a small number of PH patients, acute inhaled ADM has been shown to improve selectively the hemodynamic parameters in the pulmonary system and increased exercise capacity ${ }^{96}$. Multi-center, randomized, controlled clinical trials should be conducted to evaluate the long-term safety and efficacy of ADM, to be considered as a future treatment target in the $\mathrm{PH}^{9}$. 4. Adrenomedullin2/Intermedin (ADM2/IMD)

ADM2/IMD has quite similar structure and function to CGRP and ADM. Therefore, it is also expected that $\mathrm{ADM}$ 2/IMD can be effective in the vascular system. In many studies, the blood pressure and vascular resistance were decreased and the heart rate was increased with the application of ADM2/IMD ${ }^{17,30,9798}$. After cardiac ischemia/reperfusion injury, the administration of ADM2/IMD increased the coronary perfusion and contractile strength of the left ventricle; reduced myocardial infarct size, hypertrophy and cardiac fibrosis ${ }^{99-101}$. In normotensive and hypertensive rats, the i.v. infusion of ADM2/IMD increased cardiac output by reducing total peripheral vascular resistance ${ }^{102}$. ADM2/IMD has been shown to be a potent vasodilator in many vessel beds such as pulmonary, renal and abdominal arteries ${ }^{103-106}$. 
$\mathrm{CGRP}_{8-37}$ and $\mathrm{ADM}$ receptor antagonist $\mathrm{AM}_{22-52}$ were inhibited the effects of ADM2/IMD on cardiovascular system under both physiological and pathophysiological conditions. The CLR/RAMP receptors are responsible from the actions of ADM2/IMD in the cardiovascular system ${ }^{17,20,103}$. Although the effects of ADM2/IMD on the cardiovascular system are frequently act through the CGRP receptors, in different vascular bed, ADM2/IMD can interacts with the both CGRP and ADM receptors ${ }^{5,57}$. The ADM2/IMD-mediated response acts through CGRP receptor in the hypotension of rat systemic pressure and the vasodilation of rat coronary, carotid, supramesenteric and pulmonary arteries. However, the ADM2/IMD responses were found $\mathrm{AM}_{1}$ and $\mathrm{AM}_{2}$ receptors-mediated in pig coronary and rat renal arteries ${ }^{17,20,103,105,107,108}$. Several studies have shown that the cardiovascular effects of ADM2/IMD are endothelium-mediated and NO-dependent. In pulmonary vascular system and in aorta, the relaxation responses were inhibited by the presence of NOS inhibitor N $\omega$-Nitro-Larginine methyl ester hydrochloride (L-NAME) and in the damaged-endothelium ${ }^{99,103,109}$. The NO production was increased dose-dependently with ADM2/IMD administration in cerebral endothelial cells and pulmonary smooth muscle cells ${ }^{110,111}$.

The positive inotropic effects of ADM2/IMD and the role in the cell proliferation, apoptosis and cell migration were related with the increase of cAMP production ${ }^{112-114}$. The mRNA and protein levels of ADM2/IMD increased in right ventricles, lung tissues and plasma of hypoxia-induced pulmonary hypertensive rats ${ }^{115-117}$. The symptoms of $\mathrm{PH}$ were alleviated with ADM2/IMD treatment in rats, the right ventricular hypertrophy was prevented and the hypoxic pulmonary vascular remodeling was inhibited ${ }^{111}$. According to these studies that were performed in pulmonary hypertensive rats, ADM2/IMD is thought to be effective in $\mathrm{PH}^{118}$. In chronic hypoxiainduced PH ADM2/IMD provided potent vasodilation in pulmonary arteries of rats and intraarterial administration was reduced the perfusion pressure of hypoxic lungs. This reduction indicates the possible application of ADM2/IMD administration in the human with $\mathrm{PH}^{119,120}$.

\section{Conclusion}

Peptides of the CGRP family exhibit cardiopulmonary effects and have been investigated for long years. Especially CGRP and ADM was proposed as new vasodilator agents in the treatment of many cardiovascular disease, such as hypertension and PH. ADM2/IMD is also a potent vasodilator in cardiopulmonary system and in recent years it is shown as a new drug candidate for cardiometabolic disease ${ }^{7}$. However, further investigations should be performed for understanding these possible effects of ADM2/IMD before clinical investigations.

1. Born W, Fischer JA. The Calcitonin Peptide Family: What Can We Learn from Receptor Knock Out and Transgenic Mice. In: Hay DL, Dickerson IM, eds. The Calcitonin Gene-related Peptide Family Form, Function and Future Perspectives. Springer Dordrecht Heidelberg London New York: Springer; 2010:75-86. 2. Ghatta S, Ramarao P. Increased contractile responses to 5-Hydroxytryptamine and Angiotensin II in high fat diet fed rat thoracic aorta. Lipids Health Dis 2004;3:19.

3. Wimalawansa SJ. Amylin, calcitonin gene-related peptide, calcitonin, and adrenomedullin: a peptide superfamily. Crit Rev Neurobiol 1997;11:167-239.

4. Muff R, Born W, Fischer JA. Adrenomedullin and related peptides: receptors and accessory proteins. Peptides 2001;22:1765-72.

5. Brain SD, Grant AD. Vascular actions of calcitonin gene-related peptide and adrenomedullin. Physiol Rev 2004;84:903-34

6. Ren YS, Yang JH, Zhang J, et al. Intermedin 1-53 in central nervous system elevates arterial blood pressure in rats. Peptides 2006;27:74-9.

7. Zhang SY, Xu MJ,Wang X. Adrenomedullin 2/intermedin: a putative drug candidate for treatment of cardiometabolic diseases. Br J Pharmacol 2018;175:1230-40.

8. Nagaya N, Kangawa K. Adrenomedullin in the treatment of pulmonary hypertension. Peptides 2004;25:2013-8.

9. Raja SG, Raja SM. Treating pulmonary arterial hypertension: current treatments and future prospects. Ther Adv Chronic Dis 2011;2:359-70.

10. Copp DH. Calcitonin: discovery, development, and clinical application. Clin Invest Med 1994;17:26877.

Copp DH, Cameron EC. Demonstration of a hypocalcemic factor (calcitonin) in commercial parathyroid extract. Science 1961;134:2038.

Westermark P, Wernstedt C, Wilander E, Sletten K. A novel peptide in the calcitonin gene related peptide family as an amyloid fibril protein in the endocrine pancreas. Biochem Biophys Res Commun 1986;140:827-31.

13. Russell FA, King R, Smillie SJ, Kodji X, Brain SD. Calcitonin gene-related peptide: physiology and pathophysiology. Physiol Rev 2014;94:1099-142.

14. Kitamura K, Sakata J, Kangawa K, Kojima M, Matsuo H, Eto T. Cloning and characterization of cDNA encoding a precursor for human adrenomedullin. Biochem Biophys Res Commun 1993;194:720-5. 
15. Sugo S, Minamino N, Shoji H, et al. Production and secretion of adrenomedullin from vascular smooth muscle cells: augmented production by tumor necrosis factor-alpha. Biochem Biophys Res Commun 1994;203:719-26.

16. Sugo S, Minamino N, Kangawa K, et al. Endothelial cells actively synthesize and secrete adrenomedullin. Biochem Biophys Res Commun 1994;201:1160-6.

17. Roh J, Chang CL, Bhalla A, Klein C, Hsu SY. Intermedin is a calcitonin/calcitonin gene-related peptide family peptide acting through the calcitonin receptor-like receptor/receptor activity-modifying protein receptor complexes. J Biol Chem 2004;279:7264-74.

18. Takei Y, Inoue K, Ogoshi M, Kawahara T, Bannai H, Miyano S. Identification of novel adrenomedullin in mammals: a potent cardiovascular and renal regulator. FEBS Lett 2004;556:53-8.

19. Taylor MM, Bagley SL, Samson WK. Intermedin/adrenomedullin-2 acts within central nervous system to elevate blood pressure and inhibit food and water intake. Am J Physiol Regul Integr Comp Physiol 2005;288:R919-27.

20. Kobayashi Y, Liu YJ, Gonda T, Takei Y. Coronary vasodilatory response to a novel peptide adrenomedullin 2. Clin Exp Pharmacol Physiol 2004;31 Suppl 2:S49-50.

21. Takei Y, Hyodo S, Katafuchi T, Minamino N. Novel fish-derived adrenomedullin in mammals: structure and possible function. Peptides 2004;25:1643-56.

22. Takahashi K, Kikuchi K, Maruyama Y, et al. Immunocytochemical localization of adrenomedullin 2/intermedin-like immunoreactivity in human hypothalamus, heart and kidney. Peptides 2006;27:1383-9.

23. Keith IM, Ekman R. Dynamic aspects of regulatory lung peptides in chronic hypoxic pulmonary hypertension. Exp Lung Res 1992;18:205-24.

24. Keith IM, Tjen ALS, Kraiczi H, Ekman R. Three-week neonatal hypoxia reduces blood CGRP and causes persistent pulmonary hypertension in rats. Am J Physiol Heart Circ Physiol 2000;279:H1571-8.

25. Tjen ALS, Ekman, R., Lippton, H., Cary, J., Keith, I. . CGRP and somatostatin modulate chronic hypoxic pulmonary hypertension. American Journal of Phsiology 1992;263:681-90.

26. Qing X, Svaren J, Keith IM. mRNA expression of novel CGRP1 receptors and their activity-modifying proteins in hypoxic rat lung. Am J Physiol Lung Cell Mol Physiol 2001;280:L547-54.

27. Kuestner RE, Elrod RD, Grant FJ, et al. Cloning and characterization of an abundant subtype of the human calcitonin receptor. Mol Pharmacol 1994;46:246-55.

28. Fluhmann B, Muff R, Hunziker W, Fischer JA, Born W. A human orphan calcitonin receptor-like structure. Biochem Biophys Res Commun 1995;206:341-7.

29. Njuki F, Nicholl CG, Howard A, et al. A new calcitonin-receptor-like sequence in rat pulmonary blood vessels. Clin Sci (Lond) 1993;85:385-8.

30. Pan CS, Yang JH, Cai DY, et al. Cardiovascular effects of newly discovered peptide intermedin/adrenomedullin 2. Peptides 2005;26:1640-6.

31. Park K-Y, Russo AF. Genetic Regulation of CGRP and Its Actions. In: Hay DL, Dickerson IM, eds. The Calcitonin Gene-related Peptide Family Form, Function and Future Perspectives. Springer Dordrecht Heidelberg London New York: Springer; 2010:97-114.

32. Juaneda C, Dumont Y, Quirion R. The molecular pharmacology of CGRP and related peptide receptor subtypes. Trends Pharmacol Sci 2000;21:432-8.

33. McLatchie LM, Fraser NJ, Main MJ, et al. RAMPs regulate the transport and ligand specificity of the calcitonin-receptor-like receptor. Nature 1998;393:333-9.

34. Muff R, Buhlmann N, Fischer JA, Born W. An amylin receptor is revealed following co-transfection of a calcitonin receptor with receptor activity modifying proteins-1 or -3. Endocrinology 1999;140:2924-7.

35. Just R. S, J., Furness, S.G.B, Christopoulos,A., Sexton,P.M. Understanding Amylin Receptors. In: Hay DL, Dickerson IM, eds. The Calcitonin Gene-related Peptide Family Form, Function and Future Perspectives. Springer Dordrecht Heidelberg London New York: Springer; 2010:41-57.

36. Nagae T, Mukoyama M, Sugawara A, et al. Rat receptor-activity-modifying proteins (RAMPs) for adrenomedullin/CGRP receptor: cloning and upregulation in obstructive nephropathy. Biochem Biophys Res Commun 2000;270:89-93.

37. Cottrell GS, Roosterman D, Marvizon JC, et al. Localization of calcitonin receptor-like receptor and receptor activity modifying protein 1 in enteric neurons, dorsal root ganglia, and the spinal cord of the rat. $\mathrm{J}$ Comp Neurol 2005;490:239-55.

38. Autelitano DJ, Ridings R. Adrenomedullin signalling in cardiomyocytes is dependent upon CRLR and RAMP2 expression. Peptides 2001;22:1851-7.

39. Kamitani S, Asakawa M, Shimekake Y, Kuwasako K, Nakahara K, Sakata T. The RAMP2/CRLR complex is a functional adrenomedullin receptor in human endothelial and vascular smooth muscle cells. FEBS Lett 1999;448:111-4. 
40. Evans BN, Rosenblatt MI, Mnayer LO, Oliver KR, Dickerson IM. CGRP-RCP, a novel protein required for signal transduction at calcitonin gene-related peptide and adrenomedullin receptors. J Biol Chem 2000;275:31438-43.

41. Young A. Cardiovascular effects. Adv Pharmacol 2005;52:239-50.

42. Young AA, Crocker LB, Wolfe-Lopez D, Cooper GJ. Daily amylin replacement reverses hepatic glycogen depletion in insulin-treated streptozotocin diabetic rats. FEBS Lett 1991;287:203-5.

43. Young A, Kolterman O, Hall J. Amylin innocent in essential hypertension? Diabetologia 1999;42:1029.

44. Bell D, McDermott BJ. Activity of amylin at CGRP1-preferring receptors coupled to positive contractile response in rat ventricular cardiomyocytes. Regul Pept 1995;60:125-33.

45. Kaygisiz Z, Ozden H, Erkasap N, et al. Positive inotropic, positive chronotropic and coronary vasodilatory effects of rat amylin: mechanisms of amylin-induced positive inotropy. Acta Physiol Hung 2010;97:362-74.

46. Brain SD, Cambridge H. Calcitonin gene-related peptide: vasoactive effects and potential therapeutic role. Gen Pharmacol 1996;27:607-11.

47. Brain SD, Tippins JR, Morris HR, MacIntyre I, Williams TJ. Potent vasodilator activity of calcitonin gene-related peptide in human skin. J Invest Dermatol 1986;87:533-6.

48. Deng PY, Li YJ. Calcitonin gene-related peptide and hypertension. Peptides 2005;26:1676-85.

49. Li Y, Zhang Y, Furuyama K, et al. Identification of adipocyte differentiation-related regulatory element for adrenomedullin gene repression (ADRE-AR) in 3T3-L1 cells. Peptides 2006;27:1405-14.

50. Ando K, Pegram BL, Frohlich ED. Hemodynamic effects of calcitonin gene-related peptide in spontaneously hypertensive rats. Am J Physiol 1990;258:R425-9.

51. Gardiner SM, Compton AM, Kemp PA, Bennett T, Foulkes R, Hughes B. Regional haemodynamic effects of prolonged infusions of human alpha-calcitonin gene-related peptide in conscious, Long Evans rats. $\mathrm{Br}$ J Pharmacol 1991;103:1509-14.

52. Wu D, Bassuk J, Adams JA. Calcitonin gene-related peptide protects against whole body ischemia in a porcine model of cardiopulmonary resuscitation. Resuscitation 2003;59:139-45.

53. Champion HC, Bivalacqua TJ, Lambert DG, McNamara DB, Kadowitz PJ. The influence of candesartan and PD123319 on responses to angiotensin II in the hindquarters vascular bed of the rat. J Am Soc Nephrol 1999;10 Suppl 11:S95-7.

54. Mulderry PK, Ghatei MA, Spokes RA, et al. Differential expression of alpha-CGRP and beta-CGRP by primary sensory neurons and enteric autonomic neurons of the rat. Neuroscience 1988;25:195-205.

55. Tjen ALS, Ekman R, Lippton H, Cary J, Keith I. CGRP and somatostatin modulate chronic hypoxic pulmonary hypertension. Am J Physiol 1992;263:H681-90.

56. Tam CW, Husmann K, Clark NC, et al. Enhanced vascular responses to adrenomedullin in mice overexpressing receptor-activity-modifying protein 2. Circ Res 2006;98:262-70.

57. Bell D, McDermott BJ. Calcitonin gene-related peptide in the cardiovascular system: characterization of receptor populations and their (patho)physiological significance. Pharmacol Rev 1996;48:253-88.

58. Marshall I. Mechanism of vascular relaxation by the calcitonin gene-related peptide. Ann N Y Acad Sci 1992;657:204-15.

59. Hirata Y, Takagi Y, Takata S, Fukuda Y, Yoshimi H, Fujita T. Calcitonin gene-related peptide receptor in cultured vascular smooth muscle and endothelial cells. Biochem Biophys Res Commun 1988;151:1113-21.

60. Crossman DC, Dashwood MR, Brain SD, McEwan J, Pearson JD. Action of calcitonin gene-related peptide upon bovine vascular endothelial and smooth muscle cells grown in isolation and co-culture. $\mathrm{Br} \mathrm{J}$ Pharmacol 1990;99:71-6.

61. Han SP, Naes L, Westfall TC. Calcitonin gene-related peptide is the endogenous mediator of nonadrenergic-noncholinergic vasodilation in rat mesentery. J Pharmacol Exp Ther 1990;255:423-8.

62. Edvinsson L. Calcitonin gene-related peptide (CGRP) and the pathophysiology of headache: therapeutic implications. CNS Drugs 2001;15:745-53.

63. Yoshimoto R, Mitsui-Saito M, Ozaki H, Karaki H. Effects of adrenomedullin and calcitonin gene-

related peptide on contractions of the rat aorta and porcine coronary artery. Br J Pharmacol 1998;123:1645-54.

64. Nelson MT, Huang Y, Brayden JE, Hescheler J, Standen NB. Arterial dilations in response to calcitonin gene-related peptide involve activation of K+ channels. Nature 1990;344:770-3.

65. Maggi CA. Tachykinins and calcitonin gene-related peptide (CGRP) as co-transmitters released from

peripheral endings of sensory nerves. Prog Neurobiol 1995;45:1-98.

66. Wellman GC, Quayle JM, Standen NB. ATP-sensitive K+ channel activation by calcitonin gene-related peptide and protein kinase A in pig coronary arterial smooth muscle. J Physiol 1998;507 ( Pt 1):117-29.

67. Edvinsson L, Fredholm BB, Hamel E, Jansen I, Verrecchia C. Perivascular peptides relax cerebral arteries concomitant with stimulation of cyclic adenosine monophosphate accumulation or release of an endothelium-derived relaxing factor in the cat. Neurosci Lett 1985;58:213-7. 
68. Strecker T, Dieterle A, Reeh PW, Weyand M, Messlinger K. Stimulated release of calcitonin generelated peptide from the human right atrium in patients with and without diabetes mellitus. Peptides 2006;27:3255-60.

69. Isaka M, Imamura M, Sakuma I, Makino Y, Shiiya N, Yasuda K. Cardiopulmonary bypass influences the plasma levels of calcitonin gene-related peptides in dogs: effects of hemofiltration and hemodilution. Res Vet Sci 2007;82:110-4.

70. Gray DW, Marshall I. Nitric oxide synthesis inhibitors attenuate calcitonin gene-related peptide endothelium-dependent vasorelaxation in rat aorta. Eur J Pharmacol 1992;212:37-42.

71. Meens MJ, Fazzi GE, van Zandvoort MA, De Mey JG. Calcitonin gene-related peptide selectively relaxes contractile responses to endothelin-1 in rat mesenteric resistance arteries. J Pharmacol Exp Ther 2009;331:87-95.

72. Feng CJ, Kang B, Kaye AD, Kadowitz PJ, Nossaman BD. L-NAME modulates responses to adrenomedullin in the hindquarters vascular bed of the rat. Life Sci 1994;55:PL433-8.

73. Miura K, Ebara T, Okumura M, et al. Attenuation of adrenomedullin-induced renal vasodilatation by NG-nitro L-arginine but not glibenclamide. Br J Pharmacol 1995;115:917-24.

74. Hirata Y, Hayakawa H, Suzuki Y, et al. Mechanisms of adrenomedullin-induced vasodilation in the rat kidney. Hypertension 1995;25:790-5.

75. He H, Bessho H, Fujisawa Y, et al. Effects of a synthetic rat adrenomedullin on regional hemodynamics in rats. Eur J Pharmacol 1995;273:209-14.

76. Khan AI, Kato J, Kitamura K, Kangawa K, Eto T. Hypotensive effect of chronically infused adrenomedullin in conscious Wistar-Kyoto and spontaneously hypertensive rats. Clin Exp Pharmacol Physiol 1997;24:139-42.

77. Shimekake Y, Nagata K, Ohta S, et al. Adrenomedullin stimulates two signal transduction pathways, cAMP accumulation and Ca2+ mobilization, in bovine aortic endothelial cells. J Biol Chem 1995;270:4412-7.

78. Terata K, Miura H, Liu Y, Loberiza F, Gutterman DD. Human coronary arteriolar dilation to adrenomedullin: role of nitric oxide and K(+) channels. Am J Physiol Heart Circ Physiol 2000;279:H2620-6.

79. Hinson JP, Kapas S, Smith DM. Adrenomedullin, a multifunctional regulatory peptide. Endocr Rev 2000;21:138-67.

80. Gumusel B, Hao Q, Hyman AL, et al. Analysis of responses to adrenomedullin-(13-52) in the pulmonary vascular bed of rats. Am J Physiol 1998;274:H1255-63.

81. Parkes DG, May CN. Direct cardiac and vascular actions of adrenomedullin in conscious sheep. Br J Pharmacol 1997;120:1179-85.

82. Stangl D, Muff R, Schmolck C, Fischer JA. Photoaffinity labeling of rat calcitonin gene-related peptide receptors and adenylate cyclase activation: identification of receptor subtypes. Endocrinology 1993;132:744-50.

83. Majid DS, Kadowitz PJ, Coy DH, Navar LG. Renal responses to intra-arterial administration of adrenomedullin in dogs. Am J Physiol 1996;270:F200-5.

84. Nossaman BD, Feng CJ, Kaye AD, et al. Pulmonary vasodilator responses to adrenomedullin are reduced by NOS inhibitors in rats but not in cats. Am J Physiol 1996;270:L782-9.

85. Champion HC, Lambert DG, McWilliams SM, et al. Comparison of responses to rat and human adrenomedullin in the hindlimb vascular bed of the cat. Regul Pept 1997;70:161-5.

86. Champion HC, Wang R, Shenassa BB, et al. Adrenomedullin induces penile erection in the cat. Eur J Pharmacol 1997;319:71-5.

87. Champion HC, Wang R, Santiago JA, et al. Comparison of responses to adrenomedullin and calcitonin gene-related peptide in the feline erection model. J Androl 1997;18:513-21.

88. Lang MG, Paterno R, Faraci FM, Heistad DD. Mechanisms of adrenomedullin-induced dilatation of cerebral arterioles. Stroke 1997;28:181-5.

89. Sabates BL, Pigott JD, Choe EU, et al. Adrenomedullin mediates coronary vasodilation through adenosine receptors and KATP channels. J Surg Res 1997;67:163-8.

90. Brain SD, Poyner DR, Hill RG. CGRP receptors: a headache to study, but will antagonists prove therapeutic in migraine? Trends Pharmacol Sci 2002;23:51-3.

91. Dewachter L, Dewachter C, Naeije R. New therapies for pulmonary arterial hypertension: an update on current bench to bedside translation. Expert Opin Investig Drugs 2010;19:469-88.

92. Zhao L, Brown LA, Owji AA, et al. Adrenomedullin activity in chronically hypoxic rat lungs. Am J Physiol 1996;271:H622-9.

93. Nagaya N, Nishikimi T, Uematsu M, et al. Haemodynamic and hormonal effects of adrenomedullin in patients with pulmonary hypertension. Heart 2000;84:653-8.

94. Vizza CD, Letizia C, Sciomer S, et al. Increased plasma levels of adrenomedullin, a vasoactive peptide, in patients with end-stage pulmonary disease. Regul Pept 2005;124:187-93.

95. Kakishita M, Nishikimi T, Okano Y, et al. Increased plasma levels of adrenomedullin in patients with pulmonary hypertension. Clin Sci (Lond) 1999;96:33-9. 
96. Nagaya N, Kyotani S, Uematsu M, et al. Effects of adrenomedullin inhalation on hemodynamics and exercise capacity in patients with idiopathic pulmonary arterial hypertension. Circulation 2004;109:351-6.

97. Takei Y, Joss JM, Kloas W, Rankin JC. Identification of angiotensin I in several vertebrate species: its structural and functional evolution. Gen Comp Endocrinol 2004;135:286-92.

98. Dong F, Taylor MM, Samson WK, Ren J. Intermedin (adrenomedullin-2) enhances cardiac contractile function via a protein kinase C- and protein kinase A-dependent pathway in murine ventricular myocytes. J Appl Physiol (1985) 2006;101:778-84.

99. Yang JH, Jia YX, Pan CS, et al. Effects of intermedin(1-53) on cardiac function and ischemia/reperfusion injury in isolated rat hearts. Biochem Biophys Res Commun 2005;327:713-9.

100. Yang JH, Cai Y, Duan XH, et al. Intermedin 1-53 inhibits rat cardiac fibroblast activation induced by angiotensin II. Regul Pept 2009;158:19-25.

101. Song JQ, Teng X, Cai Y, Tang CS, Qi YF. Activation of Akt/GSK-3beta signaling pathway is involved in intermedin(1-53) protection against myocardial apoptosis induced by ischemia/reperfusion. Apoptosis 2009;14:1061-9.

102. Fujisawa Y, Nagai Y, Miyatake A, et al. Effects of adrenomedullin 2 on regional hemodynamics in conscious rats. Eur J Pharmacol 2007;558:128-32.

103. Burak Kandilci H, Gumusel B, Wasserman A, Witriol N, Lippton H. Intermedin/adrenomedullin-2 dilates the rat pulmonary vascular bed: dependence on CGRP receptors and nitric oxide release. Peptides 2006;27:1390-6.

104. Fujisawa Y, Nagai Y, Miyatake A, et al. Renal effects of a new member of adrenomedullin family, adrenomedullin2, in rats. Eur J Pharmacol 2004;497:75-80.

105. Jolly L, March JE, Kemp PA, Bennett T, Gardiner SM. Mechanisms involved in the regional haemodynamic effects of intermedin (adrenomedullin 2) compared with adrenomedullin in conscious rats. $\mathrm{Br} \mathrm{J}$ Pharmacol 2009;157:1502-13.

106. Telli G, Erac Y, Tel BC, Gumusel B. Mechanism of adrenomedullin 2/intermedin mediated vasorelaxation in rat main pulmonary artery. Peptides 2018;103:65-71.

107. Grossini E, Molinari C, Mary DA, Uberti F, Caimmi PP, Vacea G. Intracoronary intermedin 1-47 augments cardiac perfusion and function in anesthetized pigs: role of calcitonin receptors and betaadrenoreceptor-mediated nitric oxide release. J Appl Physiol (1985) 2009;107:1037-50.

108. Pfeil U, Aslam M, Paddenberg R, et al. Intermedin/adrenomedullin-2 is a hypoxia-induced endothelial peptide that stabilizes pulmonary microvascular permeability. Am J Physiol Lung Cell Mol Physiol 2009;297:L837-45.

109. Kandilci HB, Gumusel B, Lippton H. Intermedin/adrenomedullin-2 (IMD/AM2) relaxes rat main pulmonary arterial rings via cGMP-dependent pathway: role of nitric oxide and large conductance calciumactivated potassium channels (BK(Ca)). Peptides 2008;29:1321-8.

110. Chen L, Kis B, Hashimoto H, et al. Adrenomedullin 2 protects rat cerebral endothelial cells from oxidative damage in vitro. Brain Res 2006,1086:42-9.

111. Mao SZ, Fan XF, Xue F, et al. Intermedin modulates hypoxic pulmonary vascular remodeling by inhibiting pulmonary artery smooth muscle cell proliferation. Pulm Pharmacol Ther 2014;27:1-9.

112. Chen H, Wang X, Tong M, et al. Intermedin suppresses pressure overload cardiac hypertrophy through activation of autophagy. PLoS One 2013;8:e64757.

113. Li P, Sun HJ, Han Y, et al, Intermedin enhances sympathetic outflow via receptor-mediated cAMP/PKA signaling pathway in nucleus tractus solitarii of rats. Peptides 2013;47:1-6.

114. Chang CL, Roh J, Hsu SY. Intermedin, a novel calcitonin family peptide that exists in teleosts as well as in mammals: a comparison with other calcitonin/intermedin family peptides in vertebrates. Peptides 2004;25:1633-42.

115. Gong YS, Fan XF, Wu XM, et al. [Changes of intermedin/adrenomedullin 2 and its receptors in the right ventricle of rats with chronic hypoxic pulmonary hypertension]. Sheng Li Xue Bao 2007;59:210-4.

116. Gong YS, Zhang L, Guo YM, et al. [Effect of hypoxia on the expressions of intermedin/

adrenomedullin 2 in plasma and the tissues of heart and lung in rats]. Zhongguo Ying Yong Sheng Li Xue Za Zhi 2009;25:8-11.

117. Fan XF, Huang P, Gong YS, et al. [Changes of adrenomedullin 2/intermedin in the lung of rats with chronic hypoxic pulmonary hypertension]. Zhongguo Ying Yong Sheng Li Xue Za Zhi 2007;23:467-71.

118. Ni X, Zhang J, Tang C, Qi Y. Intermedin/adrenomedullin2: an autocrine/paracrine factor in vascular homeostasis and disease. Sci China Life Sci 2014;57:781-9.

119. Telli G, Tel BC, Yersal N, Korkusuz P, Gumusel B. Effect of intermedin/adrenomedullin2 on the pulmonary vascular bed in hypoxia-induced pulmonary hypertensive rats. Life Sci 2018;192:62-7.

120. Telli G, Kandilci HB, Tel BC, Gumusel B. Intermedin/Adrenomedullin 2 (IMD/AM2) is a potent vasodilator in chronic hypoxia induced pulmonary hypertensive isolated rat lungs. Faseb Journal 2016;30. 